\title{
The Research on the Relationship Between Environmental Performance and Financial Performance
}

\author{
Xiao Yan Shi, Jing Gang Ban \\ Commercial College, Tianjin University of Commerce, Tianjin, China \\ Email address: \\ 526054328@qq.com (Xiao Yan Shi),jinggang370@126.com (Jing Gang Ban) \\ *Corresponding author
}

\section{To cite this article:}

Xiao Yan Shi, Jing Gang Ban. The Research on the Relationship Between Environmental Performance and Financial Performance. Journal of Finance and Accounting. Vol. 4, No. 2, 2016, pp. 81-85. doi: 10.11648/j.jfa.20160402.18

Received: April 11, 2016; Accepted: April 16, 2016; Published: April 19, 2016

\begin{abstract}
In recent years, the destruction of the ecological environment has hindered the construction of beautiful China. The enterprise is the culprit among all the factors that cause environmental pollution, so the enterprise should pay attention to environment problems. Especially the heavy pollution industry of listed companies which destroy the environment in order to high production and good financial development. This phenomenon requires further enhancing the environmental awareness of humanity, raising the technological level of environmental protection, strengthening environmental management. With the widespread implementation of public participation in Environmental Impact Assessment in the world and the international community, the knowledge of environmental protection is popularization, making the public more aware of environmental protection. Therefore, this paper mainly discussed whether company environmental improvement can influence the companies' interests and how to affect.
\end{abstract}

Keywords: Environment Performance, Financial Performance, Heavy Pollution Industry

\section{Introduction}

The protection of the environment is one of the basic state policies of the Chinese government. In 2010, ministry of environmental protection issued 16 kinds of heavy pollution industry which should publish sewage cost, environmental report major issues on a regular basis. In 2012 the ministry of environmental protection stress that they will focus on the environmental conditions of the companies belong to the rare earth 、 regeneration of lead and other similar industries. To some degrees, the actions that Chinese government takes can prove that people have the ambitions to deal with the environment pollutions. Along with the changing consumption ideas and enhancing awareness of environmental protection, people's requirements for environment have become increasingly high, so heavy pollution industry of listed companies are required to be better. According to the above, this paper select the data of the listed companies which belongs to heavy pollution industry. Also the data from 2012 to 2014. Basis on these data this paper want to give conclusions about the relationship between company environmental performance and financial performance.

\section{Literature Review}

Telle (2006) used waste water, gas, other environmental pollutants data and reward rate (ROI) to measure environmental performance, and financial performance. Through the regression analysis, he found that there is positive significantly correlation between the environmental pollutants data and reward rate (ROI); After Sharfman (2008) had tested the positive correlation between the environmental protection data and market value, He proposed a suggestion that enterprises have to adopt an international approach to solve the problems facing us and to improve the social, environmental and economic conditions prevailing in companies according to result; Busch etc (2011) analysis the company with higher market value. He found that the more ability to improve the company's environmental pollution problems, the better company's financial performance will achieve. That means the companies environmental quality of area and utilization of resources are being improved gradually; Jun Lv (2011) With the economic and environmental data in 
china as basis, the model of the industrial waste discharge per unit and market value have been established, and the relationship between typical environmental indexes and market value was analyzed. They found relationship between environmental performance and financial performance is positive; xin Su, Peixin Wang (2015) studied the relationship between environmental performance and financial performance of listing Corporation, and found out the positive correlation between the two. The improvement of environmental performance will improve the economic benefits of enterprises;

Susi Sarumpaet (2005) found that the relationship between environmental performance and financial performance is negative. They believe that if the company pays more attention to environmental protection and environmental improvement, it will increase the environmental cost and reduce the corporate profits, so the financial performance will be affacted; QinYing (2005) represented environmental performance and financial performance were pollution emission index and ROE, Selected China Shanghai Stock Exchange listed companies in the transport industry, according to its annual report calculated from data in the corresponding index data and build models, used factor analysis of their empirical research. The research shows that the relationship between environmental pollution in paper-making industry corporate environmental protection and financial profit performance are negative correlation.

Qiao Yinhua (2006), Peloza (2009), and Henri (2010) found that corporate environmental information data and financial index data will change according to the time and specific circumstance change, therefore there is no significant correlation between the two.

\section{Empirical Research}

\subsection{Hypothesis Proposed}

Ecological civilization construction is an indispensable part in the construction of Chinese characteristic socialism. The Fifth Plenum of the 18th Central Committee of the Communist Party of China puts forward five development ideas, including green development. With the booming of the society, environment plays an important role in our life. At the same time, the heavy pollution industry of listed companies should adhere to the green development and green management. The supervision from government departments, public media, and the public will constraint the environment behavior of the corporate. Sustainable development refers to not only meet the needs of people without prejudice to future generations the ability to meet the demand. In other words, refers to economic, social, and environmental protection, coordinated development of resources, which is an inseparable system. It is necessary to achieve the purpose of economic development, but also to protect the atmosphere of human survival, fresh water, oceans, land and forest and other natural resources and the environment, so that future generations can live and work in peace and sustainable development. Sustainable development and environmental protection both links are not equivalent. Environmental protection is an important aspect of sustainable development, which is the real long-term development. The stakeholder theory of corporate governance holds that corporate is all the stakeholders. Emphasizing cooperation and maintaining co-governance among the stakeholders. The CSR theory considers corporation is not only the personal tool to make money, but also an entity undertaking the public function. The government, companies and social public are all stakeholders, so the corporate social responsibility construction activities need the joint of them. Corporation is the subject to create social wealth that shall bear economic responsibility and social responsibility. Environmental Justice theory emphasizes that the problem of environmental rights and responsibilities can be solved by the principle of equality. The core idea of the principle of equality is the fair distribution of environmental resources, social welfare and so on. Then realizing social justice and democracy and correct the unjust phenomenon that when allocating environmental benefits the behavior of the strong to the weak group could be happen.

According to the theory of Sustainable development, Stakeholder, Social justice and Environmental Justice theory, this paper argues that the development of economy can not be at the expense of the environment. Based on the theoretical analysis, this paper puts forward the hypothesis 1 .

Hypothesis1: The relationship between environmental performance and financial performance is positive in the listed companies which belongs to heavy pollution industry.

\subsection{Select Sample and Variables}

This paper selected the data of the listed company that belongs to the heavy pollution from 2012 to 2014 , in order to study relationships between financial performance and environmental performance. These data come from CSMAR database and Financial Statements of Chinese Listed company and the ministry of environmental protection had issued. This paper used SPSS 21.0 software to analyze the data, and then tested the hypothesis. First of all, this paper defined the concept Variables of environmental performance and financial performance, based on the analysis of related academic literature.

Table 1. The Definition of the Variables.

\begin{tabular}{ll}
\hline Variable Symbol & Variable Definition \\
\hline CFP & Tobin Q value \\
CEP & Pollutant drainage fee/Operation revenue \\
Size & natural logarithm of the final assets \\
State & 1represents that the actual holding are state-owned, \\
CAPI & otherwise 0 \\
Growth & Total Assets Turnover \\
\hline
\end{tabular}

Tobin Q value represents financial performance of listing Corporation. The Tobin $\mathrm{Q}$ value reflect the market value of listed companies. Pollutant drainage fee/Operation revenue represents environmental performance of listing Corporation. The more Pollutant drainage fee will be, the better 
environmental performance will be. Natural logarithm of the final asset represents size of listing Corporation. The nature of actual holding represents state of listing Corporation. We use Total Assets Turnover and Increase rate of main business revenue respectively represent CAPI and Growth of listed companies.

\subsection{Build Model}

In order to verify the hypothesis $\mathrm{H} 1$, this paper constructs the model one

\section{$\mathrm{CFP}_{\mathrm{it}}=\beta_{0}+\beta_{1} \mathrm{CEP}_{\mathrm{it}}+\beta_{2}$ Size $_{\mathrm{it}}+\beta_{3}$ State $_{\mathrm{it}}+\beta_{4} \mathrm{CAPI}_{\mathrm{it}}+\beta_{5}$ Growth $_{\mathrm{it}}+\varepsilon$}

Among them, $\beta_{0}$ is constant term, $\beta_{1}, \beta_{2}, \beta_{3}, \beta_{4}, \beta_{5}$ are coefficient of explanatory variable, $\varepsilon$ is error term

\subsection{Descriptive Statistical}

This paper makes a descriptive statistical analysis of 723 Sample Firms, and the results of statistical analysis are shown in Table 2:

Table 2. The descriptive statistical of variable.

\begin{tabular}{llllll}
\hline Variable symbol & Minimum & Maximum & Mean value & Standard deviation & Variance \\
\hline CFP & 0.128 & 9.928 & 1.324 & 1.107 & 1.226 \\
CEP & 0 & 3.272 & 0.028 & 0.217 & 0.047 \\
Size & 19.402 & 25.984 & 22.201 & 1.211 & 1.465 \\
State & 0 & 1 & 0.57 & 0.495 & 0.245 \\
CAPI & 0.001 & 3.62 & 0.705 & 0.464 & 0.215 \\
Growth & -0.987 & 2.601 & 0.091 & 0.3 & 0.09 \\
\hline
\end{tabular}

In the table, we can see the maximum data of financial performance is 9.928 , the minimum data of financial performance is 0.128 . This result illustrate that there are big changes with financial performance in different Listed companies. We also see the maximum data of environmental performance is 0 , the minimum data of environmental performance is 3. 272. This result illustrate that there are not big changes with financial performance in different Listed companies which all attach on environment government.

\subsection{Pearson Correlation Coefficient}

Before the Regression Analysis, we analyze Pearson correlation coefficient.

Table 3. The Pearson correlation coefficient of this table.

\begin{tabular}{|c|c|c|c|c|c|c|}
\hline & CFP & CEP & Size & State & CAPI & Growth \\
\hline CFP & 1. 000 & & & & & \\
\hline \multirow[t]{2}{*}{ CEP } & $-133 * *$ & 1. 000 & & & & \\
\hline & 0.001 & & & & & \\
\hline \multirow[t]{2}{*}{ Size } & $514 * *$ & 0.015 & 1. 000 & & & \\
\hline & 0.000 & 0.691 & & & & \\
\hline \multirow[t]{2}{*}{ State } & $.226^{* *}$ & 0.041 & $.395^{* *}$ & 1.000 & & \\
\hline & 0.000 & 0.284 & 0.000 & & & \\
\hline \multirow[t]{2}{*}{ CAPI } & $.075^{*}$ & $.126^{* *}$ & $141^{* *}$ & $.083^{*}$ & 1.000 & \\
\hline & 0.044 & 0.001 & 0.000 & 0.025 & & \\
\hline \multirow[t]{2}{*}{ Growth } & $081^{*}$ & 0.058 & 0.005 & 0.058 & 0.060 & 1.000 \\
\hline & 0.029 & 0.136 & 0.884 & 0.116 & 0.105 & \\
\hline
\end{tabular}

In this table 3, we find that the relationship between Tobin $\mathrm{Q}$ value and Pollutant drainage fee/Operation revenue of listing Corporation are negative correlation. In other word, Positive correlation between the environmental performance and financial performance of listing Corporation. We also find
Positive correlation between the size, state, capi, growth and financial performance of listing Corporation. Each correlation coefficient is reasonable. There is no serious multicollinearity.

\subsection{Regression Analysis}

Table 4. The summary statement of model.

\begin{tabular}{llllllll}
\hline Model & R & R2 & Regulated R2 & D-W & Error & F & Sig \\
\hline 1 & 0.570 & 0.325 & 0.319 & 1.918 & 0.927 & 53.337 \\
\hline
\end{tabular}

a. Variable: CEP, Growth, Size, CAPI, Level, State.

b. Explained Variable: CFP 
In the model, $\mathrm{R}$ is 0.570 , Regulated $\mathrm{R} 2$ is 0.319 . This goodness of fit with model is ideal. $\mathrm{D}-\mathrm{W}$ value is about2. This value shows that there is no sequence correlation. Sig. value is
0 , which shows that the model has passed the significant test at the 0.01 level, the whole model are effective.

Table 5. The coefficient about Tobin $Q$ and pollutant drainage fee.

\begin{tabular}{llllll}
\hline \multicolumn{7}{c}{ Non-Standardized Coefficients } & Standardized Coefficients & t & Sig. \\
\hline (constant) & B & standard error & & -0.011 & 0.991 \\
CEP & -0.005 & 0.435 & -0.274 & -2.321 & 0.021 \\
Size & -0.083 & 0.036 & 0.009 & 0.214 & 0.083 \\
State & 0.004 & 0.02 & 0.092 & 2.155 & 0.032 \\
CAPI & 0.102 & 0.048 & 0.107 & 2.533 & 0.012 \\
Growth & 0.15 & 0.059 & 0.114 & 2.702 & 0.007 \\
\hline
\end{tabular}

Explained Variable: CFP

From The coefficient table about Tobin Q and pollutant drainage fee, we see Tobin $\mathrm{Q}$ value and Pollutant drainage fee/Operation revenue of listing Corporation are negative correlation at the 0 . 05 level. In other word, Positive correlation between the environmental performance and financial performance of listing Corporation at the 0.05 level.

The result shows that It is urgent to solve the pollution of environment along with the people's consciousness of environmental protection. More and more heavy pollution industry of listed companies begin to protect environment Actively. Furthermore, improving environmental performance is helpful to improvement of financial performance; Positive correlation between the size and financial performance of listing Corporation at the 0.1 level. The result shows that the bigger heavy pollution industry of listed companies' size are, the better financial performance will be; Positive correlation between the state and financial performance of listing Corporation at the 0.05 level. The result shows that if the company actual holding are state-owned, its financial performance better than others. Positive correlation between the CAPI and financial performance of listing Corporation at the 0.05 level. The result shows that the quicker Total Assets Turnover of heavy pollution industry of listed companies are, the better financial performance will be. Positive correlation between the Growth and financial performance of listing Corporation at the 0.01 level. The result shows that the higher Increase rate of main business revenue of heavy pollution industry of listed companies will be, the better financial performance will be.

\section{Conclusion}

This article is mainly to study relationships between financial performance and environmental performance of Chinese heavy pollution industry in listed companies. First of all, we defined the concept of media attention, environmental performance and financial performance, based on the analysis of related academic literature. Then paper cleared up the relationship between environmental performance and financial performance and analyze the theory relations. The paper put forward the hypothesis on the basis of theoretical analysis, build a relevant model. In this paper, This article selected some companies among16 kinds of industries, which published environmental governance fee and the information of pollution. In addition, paper used SPSS 19. 0 software to analyze the data, and then tested the hypothesis. The results show that the relationship between environmental performance and financial performance is positive in the heavy pollution industry of listed companies. In the end, we propose a suggestion according to result, Properly speaking, the government should guide enterprises behavior with the help of policy and law, and change the environment management model to overcome the shortcomings in the process of the tax reform and devote a great deal of financing power to improve the environment, at the same time the government also leave no efforts to educate its public and strengthen the international cooperation.

For the heavy pollution industry of listed companies, they should pay attention to the sustainable development, so that they can improve environmental performance with the application of the advanced technology. At the same time, they should adhere to the green development and green management. For the Public media, they should supervise the environmental behavior of listed companies and promote the environmental performance and financial performance of heavy pollution industry in listed company. The Chinese government must take even more concrete measures. For example, it should let people fully realize the importance of environmental protection through education and know that destroying environment means destroying mankind themselves.

\section{Acknowledgements}

I would like to express my gratitude to all those who helped me during the writing of this thesis.

My deepest gratitude goes first and foremost to Professor Jing Gang Ban, my supervisor for his constant encouragement and guidance. He has walked me through all the stages of the writing of this thesis. Without his consistent and illuminating instruction, this thesis could not have reached its present form. Then my thanks would go to my beloved family for their loving considerations and great confidence in me all through these years. I also owe my sincere gratitude to my friends and 
my fellow classmates Mu Zi Yu, Yong Le Mao, Xi Yang who gave me their help and time in listening to me and helping me work out my problems during the difficult course of the thesis.

\section{References}

[1] Telle. K. It Pays to be Green, A Premature Conclusion. Environmental\& Resource Economics, 2006, (35): 195 -220

[2] Sharfman M, Fernando C. Environmental Risk Management and the Cost of Capital. Strategic Management Journal, 2008(29): 569-592

[3] Busch, T \& Hoffmann, V. H. How Hot Is Your Bottom Line? Linking Carbon and Financial Performance. Business \& Society, 2011, 50: 233-265

[4] Jun Lv, Shu yan Jiao. An empirical research on the relationship between environmental disclosure, environmental performance and financial performance [J]. Journal of Shanxi University of Finance and Economics, 2011 (1): 109

[5] Su Xin, Wang Peixin. An empirical research on the relationship between environmental performance and financial performance of Construction enterprise $[\mathrm{J}]$. Journal of engineering economic management of Listed Companies in China, 2015 (3)

[6] Susi Sarumpaet. 2005. The relationship between environmental performance and financial performance of Indonesian companies. Jurnal Akuntansi \& Keuangan, 7: 89-98

[7] Qin Ying, Wu Chun you. T heory and Practice Research of system engineering $[\mathrm{J}]$. An relationship research on the theory and model between enterprise environmental performance and economic performance, 2004 (8): 111-117
[8] Yin hua Joe, Peng fang Qiao, Hong Me Xuei. Corporate environmental performance evaluation index system and construction $[\mathrm{J}]$. Wuhan: Accounting Monthly (Comprehensive Edition), 2006 (11): 19-20

[9] Peloza J. The Challenge of Measuring Financial Impacts from Investments in Corporate Social Performance. Journal of Management, 2009, 35(6): 1518-1541

[10] Jean-Francois Henri. The influence of management control systems on environmental and economic performance [J]. Accounting Organizations and Society 2010, (1): 63-80

[11] Busch, T., \& Hoffmann, V. H. How Hot Is Your Bottom Line? Linking Carbon and Financial Performance. Business \& Society, 2011, 50: 233-265

[12] Lenciu lonel-Alin, Cluj-Napoca. Conceptual Model of Environmental Performance. International Journal of Business Research, 2012, 3: 55-159

[13] Jo, H, and M. A. Harjoto. The Causal Effect of Corporate Governance on Corporate Social Responsibility. Journal of Business Ethics, 2012, 106 (1): 53-72

[14] Schnietz, K. E., and M. J. Epstein. Exploring Financial Value of a Reputation for Corporate Social Responsibility during a Crisis. Corporate Reputation Review 2005, (4): 327-345

[15] Maron, I. Y. Toward a Unified Theory of the CSP-CFP Link. journal of Business Ethics, 2006, 67 (2): 191-200

[16] Freedman, M. Patten, D. Evidence of the Pernicious Effect of Financial Report Environmental Disclosures. Accounting Forum, 2004, 28: 27-41

[17] Burnett, Royce D. Hansen, Don R. 2008. Eco-efficiency: Defining a role for environmental cost management. Accounting, Organizations and Society, 6: 551-581 